\title{
EXPERIMENTAL AND THEORETICAL ANALYSIS OF AN OXAZINOQUINOXALINE DERIVATIVE FOR CORROSION INHIBITION OF AISI 1018 STEEL
}

\author{
Joherbson Deivid dos S. Pereira ${ }^{a}$, Jannyely M. Neria, Denise P. Emerenciano ${ }^{a}$, Gutto Raffyson S. de Freitas ${ }^{a}$, Maria Beatriz \\ M. Cansanção Felipe ${ }^{\mathrm{b}}$, Miguel Ângelo F. de Souza ${ }^{\mathrm{a}}$, Fabrício G. Menezes a and Maria Aparecida M. Maciela, ${ }^{a, \text { *, }, \text {, }}$ \\ anstituto de Química, Universidade Federal do Rio Grande do Norte, 59072-970 Natal - RN, Brasil \\ ${ }^{b}$ Núcleo de Pesquisa em Petróleo e Energias Renováveis, Universidade Federal do Rio Grande do Norte, 59072-970 Natal - RN,Brasil \\ 'Universidade Potiguar Laureate International Universities, Campus Salgado Filho, 59075-000 Natal - RN, Brasil
}

Recebido em 08/05/2017; aceito em 16/11/2017; publicado na web em 12/12/2017

\begin{abstract}
The inhibitory ability of an oxazinoquinoxaline derivative (OAQX) against the corrosion of AISI 1018 mild steel induced by aqueous $0.6 \mathrm{~mol} \mathrm{~L}^{-1} \mathrm{NaCl}$ solution is herein evaluated. Linear polarization resistance studies showed the inhibitory efficiency of OAQX varying from $62.75 \%$ to $75.93 \%$ with OAQX concentration ranged from $0.259 \times 10^{-4} \mathrm{~mol} \mathrm{~L}^{-1}$ to $3.243 \times 10^{-4} \mathrm{~mol} \mathrm{~L}^{-1}$. Aiming at to investigate the Tafel curves on the OAQX electrochemical behavior at saline $\left(0.6 \mathrm{~mol} \mathrm{~L}^{-1} \mathrm{NaCl}\right)$ aqueous media the linear Tafel segments of anodic and cathodic curves were extrapolated to the intersection point which afforded corrosion potential $\left(\mathrm{E}_{\text {corr }}\right)$ and corrosion current density $\left(\mathrm{i}_{\text {corr }}\right)$ data. By applying Tafel approach the efficiency of OAQX ranges from $55.30 \%$ to $87.60 \%$. In both analysis Langmuir isotherm lead to optimized adsorption parameter. The adsorption mechanism of OAQX is proposed from FTIR experiments and quantum calculations. The theoretical employed method is hybrid B3LYP combined with 6-311++G(d,p). Theoretical results showed OAQX as a promising inhibitor that form a stable protective metal-ligand film on metal surfaces, and differs from several heterocyclic compounds due to its solubility in small amount of DMSO $\left(0.627 \times 10^{-4} \mathrm{~mol} \mathrm{~L}^{-1}\right)$ which is resistant to a saline aqueous media $\left(0.6 \mathrm{~mol} \mathrm{~L}^{-1} \mathrm{NaCl}\right)$.
\end{abstract}

Keywords: oxazinoquinoxaline derivative; corrosion inhibitor; linear polarization resistance; FTIR analysis; modeling studies.

\section{INTRODUÇÃO}

Corrosion is one of the main problems found in several industrial processes since it leads to material failure and this damage cause several consequences, including pollution, risks of accidents and financial losses. ${ }^{1-5}$ Mild steels have been extensively employed in many industrial fields due to their interesting properties, easy fabrication and low cost. ${ }^{6}$ However, they are sensitive to corrosion phenomenon, and become an environmental problem. In this sense, it is important to focuses on the demand for fossil fuels from which a major application of mild steels arrives from their use in the petroleum industry. Since the largest oil sources are located underground in oceans and seas, corrosion of these materials by saline conditions has been attracting considerable attention. ${ }^{7-10}$

The addition of a corrosion inhibitor in the corrosive medium is one of the most common approaches to control corrosion process. ${ }^{11}$ In this context, since mild steels are basically composed of metallic atoms (iron, manganese, copper, among others) the choice of a corrosion inhibitor especially comes from its electron donation ability or electrostatic interaction. The chemical structure of organic compounds contain elements like oxygen, sulfur, nitrogen as well as $\pi$ bonds, which shows high electron density. In fact, heterocyclic compounds containing nitrogen, oxygen sulfur, and phosphorous have been extensively reported for their effectiveness in this field. ${ }^{2,4,12-25}$ Such important characteristic contributes to the adsorption phenomena on the metal surface ${ }^{15}$ and organic molecules containing functional groups showed to be efficient corrosion inhibitors, such as amino group which act as inhibitor on metal surfaces. On the other hand, molecular solubility and degradation aspects also must be taken into account. ${ }^{26}$ Quinoxaline (benzopyrazine) derivatives are

*e-mail: mammaciel@quimica.ufrn.br

"Programa de Pós-graduação em Biotecnologia extensively reported in literature due some relevant application such as: biological effects, ${ }^{27}$ advanced luminescent and material property, ${ }^{28}$ as well as corrosion inhibitors. ${ }^{2,4,20-25}$ Relative to this latter application, Figure 1 shows examples of quinoxaline derivatives found as good corrosion inhibitors on mild steel.

The aim of this study is to report the inhibitory ability of the compound 2-(2,3-dihydro-[1,4] oxazino[2,3-b]quinoxalin-4-yl) ethanol (OAQX) against corrosion of AISI 1018 mild steel, in saline conditions. The benzopyrazine OAQX derivative (Figure 1) was chosen because it is structurally suitable on the referred purpose due to the different Lewis basic sites which could strongly coordinate with metallic materials. The corrosion inhibitive efficiency of OAQX was evaluated based on potentiodynamic linear polarization in order to obtain polarization curves which were analyzed by polarization resistance and also by applying Tafel extrapolation methods.

The binding mechanism associated to the inhibition process is proposed by using the attenuated total reflectance FTIR analysis. In addition, a theoretical study was performed in attempt to give support to the observed experimental data and corroborate to the computational calculations importance since it has been used as a relevant tool in the corrosion field..$^{2,4,20,23,25}$ Specifically, OAQX was theoretically investigated for its optimized geometry, electronic density aspects, HOMO-LUMO energy gap and binding energy.

\section{EXPERIMENTAL}

\section{Material and methods}

The compound OAQX was prepared according to the literature, ${ }^{29}$ recrystallized from water, and dried under vacuum in the presence of phosphorous pentoxide, to yield a bright yellow crystalline solid. The solutions were prepared by dissolving $0.015 \mathrm{~g}$ of OAQX in DMSO $(0.1 \mathrm{~mL})$ and then, the stock solution was obtained by adding 
<smiles>Cc1nc2ccccc2[nH]c1=S</smiles>

[reference 4]<smiles>O=c1[nH]c2ccccc2[nH]c1=O</smiles>

[reference 24]<smiles>COc1cc(-c2cnc3ccccc3n2)ccc1O</smiles>

[reference 13]<smiles>c1ccc(-c2cc3nc4ccccc4nc3cc2-c2ccccc2)cc1</smiles>

[reference 25]

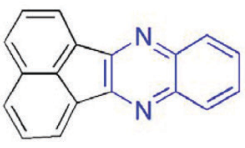

[reference 20]

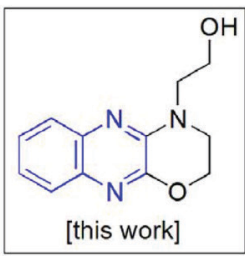

Figure 1. Examples of quinoxaline-based corrosion inhibitors previously reported and focuses the target molecule OAQX. Quinoxaline unit is detached in blue $4,13,20,24,25$

aqueous $\mathrm{NaCl}\left(0.6 \mathrm{~mol} \mathrm{~L}^{-1}\right)$ to $200 \mathrm{~mL}$ volume of the stock solution, affording $4.324 \times 10^{-4} \mathrm{~mol} \mathrm{~L}^{-1}$ of OAQX. The OAQX was tested in lower concentrations $\left(3.243 \times 10^{-4} \mathrm{~mol} \mathrm{~L}^{-1}, 2.159 \times 10^{-4} \mathrm{~mol} \mathrm{~L}^{-1}\right.$, $1.082 \times 10^{-4} \mathrm{~mol} \mathrm{~L}^{-1}, 0.541 \times 10^{-4} \mathrm{~mol} \mathrm{~L}^{-1}$, and $\left.0.259 \times 10^{-4} \mathrm{~mol} \mathrm{~L}^{-1}\right)$ which were prepared by using simple dilutions of OAQX stock solution with aqueous saline solution $\left(0.6 \mathrm{~mol} \mathrm{~L}^{-1} \mathrm{NaCl}\right)$. In that, the DMSO final concentration in the stock solution was $0.627 \times 10^{-4} \mathrm{~mol} \mathrm{~L}^{-1}$.

\section{Electrochemical assays}

Electrochemical assays were performed at room temperature $(300 \mathrm{~K})$ by using a thermostatic three electrode electrochemical cell assembly ( $30 \mathrm{~mL}$ of capacity) containing the working electrode AISI 1018 [(in wt.\%) $0.18 \mathrm{C} ; 0.85 \mathrm{Mn}$; $0.04 \mathrm{P}$; $0.05 \mathrm{~S}$ and the remainder iron] mild steel (Code: EL4123772800000) which was obtained from IEC (Instalações e Engenharia de Corrosão Ltda) with a $0.273 \mathrm{~cm}^{2}$ surface circle area, and a platinum auxiliary electrode with cylindrical area $\left(0.628 \mathrm{~cm}^{2}\right)$ as well as the reference electrode $\left(\mathrm{Ag} / \mathrm{AgCl}, 3.0 \mathrm{~mol} \mathrm{~L}^{-1} \mathrm{KCl}\right)$. The metallographic study of the AISI 1018 mild steel used in the working electrode is presented (Figure 1S) and discussed in the Supplementary Material.

The working electrode was immersed in $\mathrm{NaCl}\left(0.6 \mathrm{~mol} \mathrm{~L}^{-1}\right)$ for 15 minutes before each experiment, with and without the addition of the OAQX test sample, without stirring. The polarization measurements were performed using a scan rate of $1 \mathrm{mV} \mathrm{s}^{-1}$ in the potential range of $\pm 500 \mathrm{mV}$ around the open circuit potential $\left(\mathrm{E}_{\mathrm{ocp}}\right)$. The polarization curves were performed by applying an Autolab PGSTAT $302 \mathrm{~N}$ potentiostat/galvanostat and the data were analyzed using GPES version 4.9 software in order to obtain polarization curves and corrosion parameters.

Polarization resistance $(\mathrm{Rp})$ was determined by performing a linear regression tangent to the data from $30 \mathrm{mV}$ cathodic to $30 \mathrm{mV}$ anodic relative to the observed corrosion potential. The Rp was calculated from inverse of the slope (1/slope). Corrosion inhibition efficiencies at different OAQX concentrations $\left(3.243 \times 10^{-4} \mathrm{~mol} \mathrm{~L}^{-1}\right.$, $2.159 \times 10^{-4} \mathrm{~mol} \mathrm{~L}^{-1}, 1.082 \times 10^{-4} \mathrm{~mol} \mathrm{~L}^{-1}, 0.541 \times 10^{-4} \mathrm{~mol} \mathrm{~L}^{-1}$, and $0.259 \times 10^{-4} \mathrm{~mol} \mathrm{~L}^{-1}$ ) were calculated using Equation 1. The finding results are presented in Table 1.

$$
\eta_{P}(\%)=\left[\left(\frac{R p-R p_{o}}{R_{p}}\right)\right] \times 100
$$

where "Rp" is the polarization resistance $(\mathrm{Ohm})$ in the presence of OAQX at different concentrations, and $\mathrm{Rp}_{\mathrm{o}}$ is the blank solution $\left(0.6 \mathrm{~mol} \mathrm{~L}{ }^{-1} \mathrm{NaCl}\right)$ polarization resistance $(\mathrm{Ohm})$.
The anodic and cathodic polarization curves for AISI 1018 mild steel on sodium chloride solution $\left(0.6 \mathrm{~mol} \mathrm{~L}^{-1} \mathrm{NaCl}\right)$ and DMSO $\left(0.627 \times 10^{-4} \mathrm{~mol} \mathrm{~L}^{-1}\right)$ were presented in the Supplementary Material (Figure S2).

The surface coverage of AISI 1018 mild steel by OAQX at different concentrations was calculated from Equation 2, which was applied on Langmuir and Temkin isotherms (Equations 3 and 4) calculations and the standard free energy of inhibitor adsorption on the metal surface was calculated using Equation 5.

Surface coverage: $\theta=\frac{R p-R p_{o}}{R_{p}}$

Langmuir: $\frac{C}{\theta}=\frac{1}{K_{a d s}}+C$

Temkin: $\log \left(\frac{\theta}{C}\right)=\log \left(K_{a d s}\right)-g \theta$

Adsorption Gibbs free energy: $\Delta G_{a d s}^{0}=-R T \times \ln \left(55.5 \times K_{a d s}\right)$

where " $\theta$ " is the surface coverage, " $C$ " is the concentration of OAQX at different concentrations, " $\mathrm{K}_{\mathrm{ads}}$ " is the adsorption-desorption constant, " $\mathrm{g}$ " is the degree of lateral interaction between adsorbed molecules, $\Delta G_{a d s}^{0}$ is the Gibbs adsorption free energy $\left(\mathrm{kJ} \mathrm{mol}^{-1}\right)$, " $\mathrm{R}$ " is the universal constant of gases $\left(\mathrm{J} \mathrm{K}^{-1} \mathrm{~mol}^{-1}\right)$, " $\mathrm{T}$ " is the temperature $(300 \mathrm{~K})$, and 55.5 is the molar concentration $\left(\mathrm{mol} \mathrm{L}^{-1}\right)$ of water in the solution. The finding results are presented in Table 2 .

The linear Tafel segments of anodic and cathodic curves were extrapolated to the intersection point, aiming at corrosion potential $\left(\mathrm{E}_{\text {corr }}\right)$ and corrosion current density $\left(\mathrm{i}_{\text {corr }}\right)$ data. The inhibition efficiencies at different inhibitor concentrations were calculated using Equation 6.

Inhibitory efficiency $\left(\eta_{P}\right)=\left[\left(\frac{i_{o}-i}{i_{o}}\right)\right] \times 100 \%$

where " $\mathrm{i}$ " is the corrosion current density $\left(\mathrm{A} \mathrm{cm}^{-2}\right)$ in the presence of OAQX at different concentrations, and " $\mathrm{i}_{\mathrm{o}}$ " is the corrosion current density $\left(\mathrm{A} \mathrm{cm}^{-2}\right)$ of the blank solution $\left(0.6 \mathrm{~mol} \mathrm{~L}^{-1} \mathrm{NaCl}\right)$.

The polarization measurements were performed by using a scan rate of $1 \mathrm{mV} \mathrm{s}^{1}$ in the potential range of $\pm 500 \mathrm{mV}$ around the open circuit potential $\left(\mathrm{E}_{\mathrm{ocp}}\right)$, according to Figure 2.

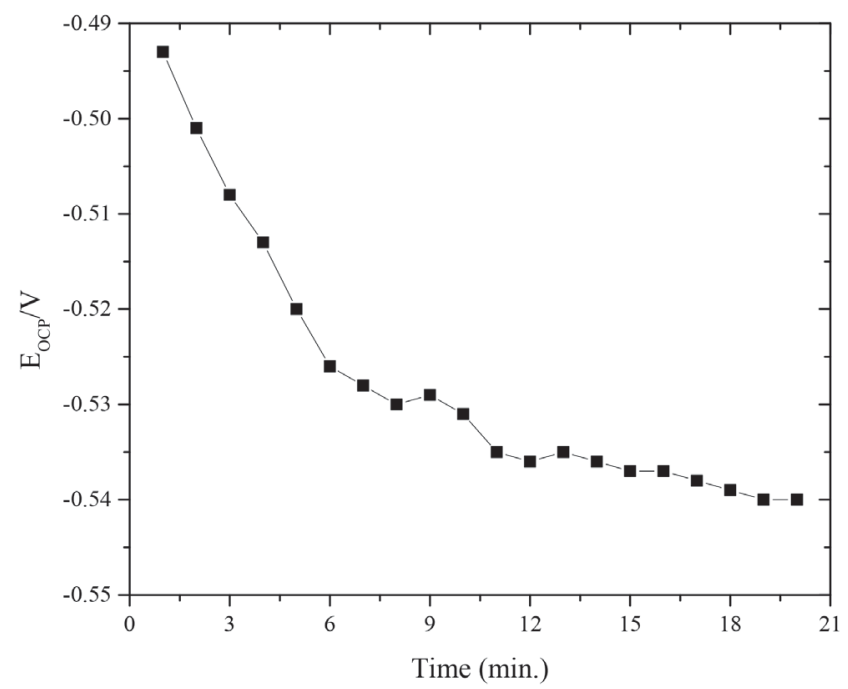

Figure 2. Open circuit potential $\left(E_{O C P}\right)$ of carbon steel immersed in a solution containing $0.1 \mathrm{~mL} \mathrm{DMSO}$ and $\mathrm{NaCl}\left(0.6 \mathrm{~mol} \mathrm{~L}^{-1}\right)$ 
The inhibition efficiency of OAQX at different concentrations, was also analyzed by Tafel extrapolation methods by using Equation 7, which is according to the obtained data from Equation 6. The finding results are presented in Table 3 .

$$
\Delta V=A \times \log _{e}\left(\frac{i}{i_{o}}\right)
$$

where $\Delta \mathrm{V}$ is the overpotential (Volts), "A" is the Tafel slope, " $\mathrm{i}$ " is the current density $\left(\mathrm{A} \mathrm{cm}^{-2}\right)$ of OAQX at different concentrations, and $\mathrm{i}_{\mathrm{o}}$ is the corrosion current density $\left(\mathrm{A} \mathrm{cm}^{-2}\right)$ of the blank solution $\left(0.6 \mathrm{~mol} \mathrm{~L}^{-1} \mathrm{NaCl}\right)$.

The surface coverage of AISI 1018 mild steel by OAQX was calculated from Equation 2, which was used in Langmuir and Temkin isotherms (Equations 3 and 4) calculations and the standard free energy of inhibitor adsorption on the metal surface, and was calculated using Equation 5. The finding results are presented in Table 4.

\section{FTIR spectroscopy}

Attenuated total reflectance FTIR analysis were performed using a Bruker FT-IR Vertex 70 instrument and the spectra were collected from 16 scans at a resolution of $4 \mathrm{~cm}^{-1}$. Changes in the FTIR spectra were evaluated in the mild steel specimen with a $0.273 \mathrm{~cm}^{2}$ surface circle area after being exposed to $50 \mathrm{~mL}$ of $0.6 \mathrm{~mol} \mathrm{~L}^{-1} \mathrm{NaCl}$ solutions, at $303 \mathrm{~K}$ for $72 \mathrm{~h}$, in the absence and presence of the inhibitor OAXQ (3.243 x $\left.10^{-4} \mathrm{~mol} \mathrm{~L}^{-1}\right)$. FTIR spectrum of pure OAQX was obtained from the same equipment.

\section{Computational details}

Structural and electronic parameters of the OAQX quinoxaline derivative were obtained in gas phase by using B3LYP method ${ }^{30}$ combined with $6-311++\mathrm{G}(\mathrm{d}, \mathrm{p})$ basis set method in a Gaussian Program. ${ }^{31}$ Atomic charges were calculated from the Chelpg method ${ }^{32}$ which allowed for building a potential energy surface for the referred inhibitor. Quantum computation study also provided the dipole moment $(\mu)$ of the organic compound, as well as the energies of the highest occupied molecular orbital $\left(\mathrm{E}_{\text {номо }}\right)$ and the lower unoccupied molecular orbital ( $\left.\mathrm{E}_{\text {LUMO }}\right)$.

Electronic affinity (A) and ionization potential (I) were obtained from these values by applying Equations 8 and 9, respectively. ${ }^{33}$ With the values of A and I, absolute electronegativity $(\chi)$ and global hardness $(\gamma)$ were obtained from Equations 10 and 11, respectively, and then provided the fraction of electron transferred $\Delta \mathrm{N}$ from Equation $12 .{ }^{33}$

For the calculation of $\Delta \mathrm{N}$, the absolute electronegativity of an iron atom and the OAQX are represented by $\chi_{\mathrm{Fe}}$ and $\chi_{\text {inh }}$, respectively. Also, $\gamma_{\mathrm{Fe}}$ and $\gamma_{\text {inh }}$ represent the absolute hardness of the iron atom and the OAQX, respectively.

The theoretical value of $\chi_{\mathrm{Fe}}$ was $7 \mathrm{eV} / \mathrm{mol}$. On the other hand, $\gamma_{\mathrm{Fe}}=0$ was considered by assuming that $\mathrm{I}=\mathrm{A}$ for the metallic bulk. ${ }^{33}$

$$
\begin{gathered}
\mathrm{A}=-\mathrm{E}_{\text {LUмо }} \\
\mathrm{I}=-\mathrm{E}_{\text {Номо }} \\
\chi=\frac{I+A}{2} \\
\gamma=\frac{I-A}{2}
\end{gathered}
$$

$$
\Delta N=\frac{\chi_{F e}-\chi_{i n h}}{2\left(\gamma_{F e}+\gamma_{i n h}\right)}
$$

\section{RESULTS AND DISCUSSION}

Nowadays, there are several examples of heterocyclic compounds acting as corrosion inhibitors in acidic media, however, the low solubility of extended aromatic heterocyclic can be assumed as a limitation for assays in neutral medium $\left(0.6 \mathrm{~mol} \mathrm{~L} \mathrm{~L}^{-1} \mathrm{NaCl}\right)$. In this sense, it is also important to focuses in the especially fact that the largest natural oil reservoirs are located at sea and largely causes corrosion damage. Corrosion is one of the main problems occurring in several industrial processes and mild steels show a broad spectrum of employment in industry, such as those associated to the petroleum field. In this sense, in this work, after the synthetic procedure, the obtained quinoxaline derivative so called OAQX was submitted to solubility evaluation in neutral conditions and then assayed against AISI 1018 mild steel, in saline corrosive conditions $\left(0.6 \mathrm{~mol} \mathrm{~L}^{-1} \mathrm{NaCl}\right)$. From this, it was found that $0.1 \mathrm{~mL}$ of DMSO which is equivalent to $0.627 \times 10^{-4}$ of DMSO in the OAQX $\left(4.324 \times 10^{-4} \mathrm{~mol} \mathrm{~L}^{-1}\right)$ stock solution, was the best media to lead OAQX homogenous solutions at its higher tested concentration $\left(3.243 \times 10^{-4} \mathrm{~mol} \mathrm{~L}^{-1}\right)$. In the sequence, the OAQX stock solution was obtained and the tested OAQX samples were prepared at lower concentrations by performing dilutions on OAQX stock solution using the saline $0.6 \mathrm{~mol} \mathrm{~L}^{-1} \mathrm{NaCl}$ solution. Then, OAQX at different concentrations $\left(3.243 \times 10^{-4} \mathrm{~mol} \mathrm{~L}^{-1}\right.$, $2.159 \times 10^{-4} \mathrm{~mol} \mathrm{~L}^{-1}, 1.082 \times 10^{-4} \mathrm{~mol} \mathrm{~L}^{-1}, 0.541 \times 10^{-4} \mathrm{~mol} \mathrm{~L}^{-1}$, and $0.259 \times 10^{-4} \mathrm{~mol} \mathrm{~L}^{-1}$ ) was evaluated as a corrosion inhibitor as described below.

\section{Electrochemical measurements}

The OAQX corrosion inhibition ability was evaluated against AISI 1018 mild steel using potentiodynamic polarization curves by means of polarization resistance $\left(\mathrm{R}_{\mathrm{p}}\right)$ performing a linear regression tangent to the data from $30 \mathrm{mV}$ cathodic to $30 \mathrm{mV}$ anodic, relative to the observed corrosion potential. In addition, the linear Tafel segments of anodic and cathodic curves were extrapolated to the intersection point, aiming at corrosion potential $\left(\mathrm{E}_{\text {corr }}\right)$ and corrosion current density $\left(\mathrm{i}_{\text {corr }}\right)$ data as well as Tafel coefficients.

The three used electrodes were immersed in the saline medium $\left(0.6 \mathrm{~mol} \mathrm{~L}^{-1} \mathrm{NaCl}\right)$ which acts as a corrosive agent and also as the control reference. Thus, OAQX inhibition efficiency was calculated using polarization resistance ( $R p)$ values applied in Equation 1. Rp is a quantitative parameter which is inversely proportional to corrosion rate and can be used to compare corrosion resistance of metals under various chemical and electrochemical conditions. Rp results showed that the OAQX inhibition efficiency varied from $62.75 \%$ to $75.93 \%$ (Table 1). with maximum inhibition at $2.159 \times 10^{-4} \mathrm{~mol} \mathrm{~L}^{-1} \mathrm{OAQX}$ concentration.

Adsorption isotherms are particularly important in order to evaluate the inhibitor behavior on metallic surface. The degree of surface coverage of various concentrations of the inhibitors was analyzed into different adsorption isotherms, being Langmuir and Temkin the best approaches for OAQX tested samples. The OAQX equilibrium constant $\left(\mathrm{K}_{\mathrm{ads}}\right)$ of adsorption from isotherm equation leads to calculate the standard free energy of adsorption (), by using Equation 5. The best fitting of the OAQX adsorption behavior on the mild steel surface was found to the Langmuir isotherm (Figure 3) with strong linearity with correlation coefficient of $\mathrm{R}^{2}=0.99$ (Table 2). However, the slope deviates from unit which is expected by this model, suggest that some lateral interaction between the adsorbed species on the metal surface is present and other than monolayer 
Table 1. Parameters obtained from polarization curves for AISI 1018 mild steel, in saline medium $\left(0.6 \mathrm{~mol} \mathrm{~L}^{-1} \mathrm{NaCl}\right)$ containing OAQX at different concentrations

\begin{tabular}{cccc}
\hline $\begin{array}{c}\text { OAQX } \\
\left(\times 10^{-4} \mathrm{~mol} \mathrm{~L}^{-1}\right)\end{array}$ & $\begin{array}{c}\mathrm{E}_{\text {corr }} \text { observed } \\
(\mathrm{V})\end{array}$ & $\begin{array}{c}\mathrm{Rp} \\
\left(\mathrm{x} 10^{3} \mathrm{Ohm}\right)\end{array}$ & $\begin{array}{c}\eta_{\mathrm{P}} \\
(\%)\end{array}$ \\
\hline 0 & -0.837 & 6.120 & 0 \\
0.259 & -0.800 & 16.43 & 62.75 \\
0.541 & -0.829 & 21.21 & 71.15 \\
1.082 & -0.736 & 22.86 & 73.24 \\
2.159 & -0.702 & 25.42 & 75.93 \\
3.243 & -0.634 & 20.29 & 69.84 \\
\hline
\end{tabular}

formation. No good correlation was found for the others tested isotherms, therefore the adopted $\mathrm{K}_{\mathrm{ads}}$ comes from the Langmuir isotherm. These parameters indicated an exothermic and spontaneous process with tendency to a chemisorption phenomena since it was found to be upon to $|20| \mathrm{kJ} \mathrm{mol}^{-1}$. These findings suggest the formation of an OAQX protective film which act in the metal surface as a barrier to charge transfer and adsorption only depends on the particle-electrode interaction.

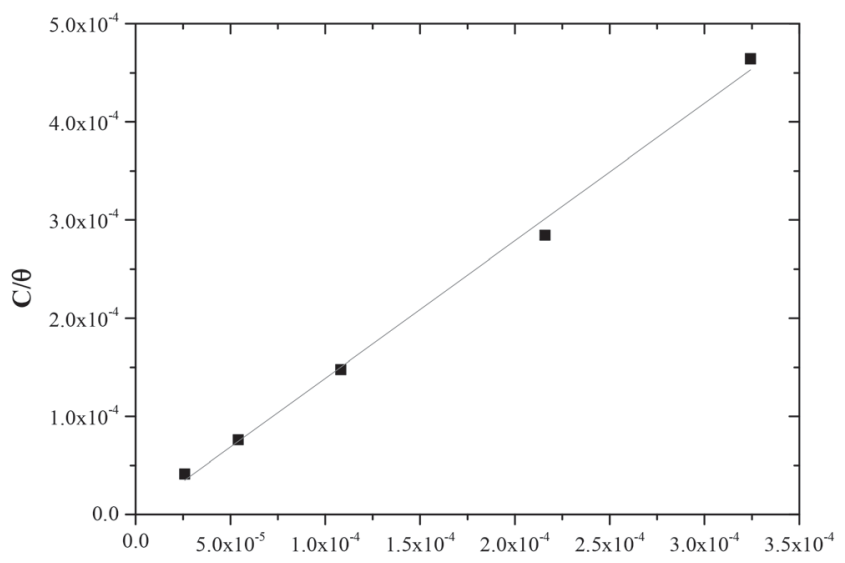

$\mathrm{C}\left(\mathrm{mol} \mathrm{L}^{-1}\right)$

Figure 3. Langmuir isotherm plot for AISI 1018 mild steel in saline medium $\left(0.6 \mathrm{~mol} \mathrm{~L}^{-1} \mathrm{NaCl}\right.$ ) containing different concentrations of OAQX at $300 \mathrm{~K}$

Table 2. Adsorption parameters for OAQX corrosion inhibitor of AISI 1018 mild steel, in saline medium $\left(0.6 \mathrm{~mol} \mathrm{~L}^{-1} \mathrm{NaCl}\right)$

\begin{tabular}{ccccc}
\hline Isotherm & Equation & $\mathrm{R}^{2}$ & $\mathrm{~K}_{\mathrm{ads}}$ & $\begin{array}{c}\Delta G_{\text {ads }}^{0} \\
\left(\mathrm{~kJ} \mathrm{~mol}^{-1}\right)\end{array}$ \\
\hline Langmuir & $\mathrm{y}=0.000001+1.402 \mathrm{X}$ & 0.99 & $1.0 \times 10^{6}$ & -44.48 \\
Temkin & $\mathrm{y}=-5.4396 \mathrm{x}+7.6821$ & 0.40 & $4.8 \times 10^{7}$ & -53.76 \\
\hline
\end{tabular}

Tafel curves and corrosion parameters obtained from the extrapolation of the Tafel region, are shown in Figure 4. The evaluated parameters included corrosion current density $\left(\mathrm{i}_{\text {corr }}\right)$ and corrosion potential $\left(\mathrm{E}_{\text {corr }}\right)$, as well as $\eta_{\mathrm{P}}$ calculated by using Equation 6 . The finding results are listed in Table 3 . The polarization measurements showed the inhibition efficiency of OAQX varying from $55.30 \%$ to $87.60 \%$ according to each OAQX tested concentration. Regarding to the potentiodynamic polarization curves (Figure 4) the anodic reaction was affected $\left(\mathrm{b}_{\text {anodic }}\right.$ increased values) showing OAQX of maximum inhibition $\left(87.60 \%\right.$ ) at OAQX $3.243 \times 10^{-4} \mathrm{~mol} \mathrm{~L}^{-1}$ concentration. Meanwhile, OAQX increased concentration shifted
$\mathrm{E}_{\text {corr }}$ to more positive potentials, but current densities were found in lower concentrations.

OAQX presented displacement of the corrosion potential for positive values correlated with the concentration increases, and Tafel curves showed OAQX to be active on anodic site. In fact, as the potential of the metal become more positive, the rates of anodic reactions increase, and the rates of the cathodic reactions decrease. This finding was verified by surface coverage obtained from Tafel curves and the applied Langmuir (Figure 5a) and Temkin (Figure $5 \mathrm{~b}$ ) isotherms, which had presented $\mathrm{R}^{2}$ values of 0.99 and 0.94 , respectively. The results are summarized in Table 4.

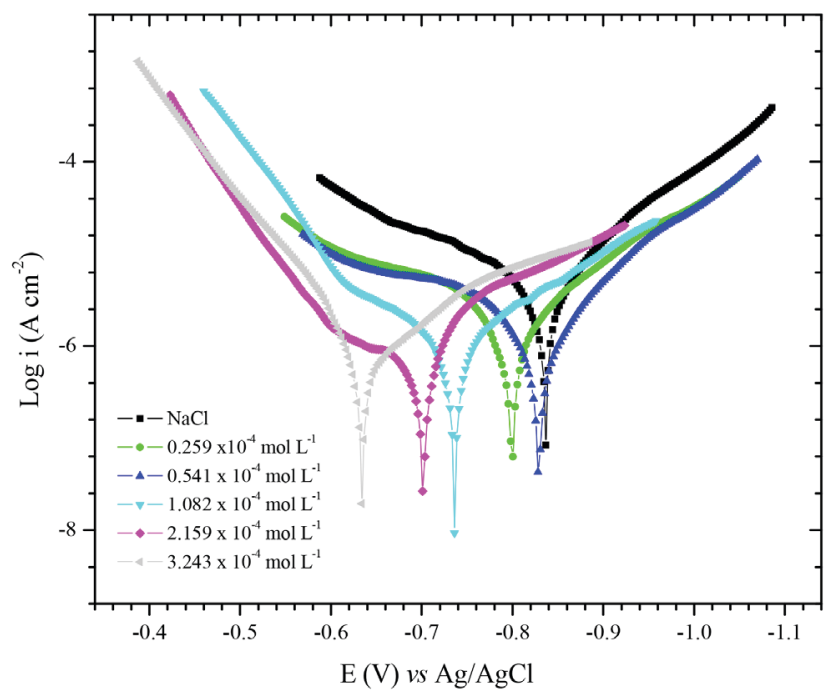

Figure 4. Anodic and cathodic polarization curves for AISI 1018 mild steel in saline medium $\left(0.6 \mathrm{~mol} \mathrm{~L} L^{-1} \mathrm{NaCl}\right)$, toward $0.259 \times 10^{-4} \mathrm{~mol} \mathrm{~L}^{-1}$ to $3.243 \times$ $10^{-4} \mathrm{~mol} \mathrm{~L}^{-1}$ of $\mathrm{OAQX}$

For this calculation, the adopted $\mathrm{K}_{\mathrm{ads}}$ comes from the Langmuir isotherm, since it was found to be the best description of the OAQX adsorption behavior on the mild steel surface $\left(\mathrm{R}^{2}=0.99\right)$ (Figure 5a) with a negative value of $\left(-36.47 \mathrm{~kJ} \mathrm{~mol}^{-1}\right)$ suggesting homogeneity of the formed OAQX film in the metallic surface, favoring the effectiveness of OAQX corrosion inhibition in the higher tested concentration $\left(3.243 \times 10^{-4} \mathrm{~mol} \mathrm{~L}^{-1}\right)$. Comparatively, Temkin isotherm presented lower correlation $\left(\mathrm{R}^{2}=0.94\right)$ (Figure $5 \mathrm{~b}$ ) with a negative value of $\left(-44.57 \mathrm{~kJ} \mathrm{~mol}^{-1}\right)$. Both models indicated exothermic and spontaneous process, considered as chemisorption phenomena, because it was found to be upon to $|20| \mathrm{kJ} \mathrm{mol}^{-1}$. These findings reinforce the above information that shows OAQX forming a protective film.

\section{FTIR spectroscopy}

FTIR experiments were carried out in attempt to understand the OAQX binds mechanism in the metal surface. Figure 6 shows the FTIR spectra $\left(700 \mathrm{~cm}^{-1}-2000 \mathrm{~cm}^{-1}\right)$ of the mild steel electrodes after $72 \mathrm{~h}$ of immersion in the solutions containing $0.6 \mathrm{~mol} \mathrm{~L}^{-1} \mathrm{NaCl}$ in the absence and presence of OAQX at the higher concentration $\left(3.243 \times 10^{-4} \mathrm{~mol} \mathrm{~L}^{-1}\right)$. For the electrode immersed in chloride medium, no bands were found in the spectra region, this characterize the absence of OAQX in the metal surface. Comparatively, OAQX FTIR spectra (as a control sample) and OAQX adsorbed on metallic surface (Figure 6a), although less defined, considerably resemble those appearing in the pure control data. This poor definition, may be considered normal for FTIR studies of adsorption phenonema. ${ }^{6,34,35}$ The region comprising around $1620 \mathrm{~cm}^{-1}-1591 \mathrm{~cm}^{-1}$ is relative to 
a)

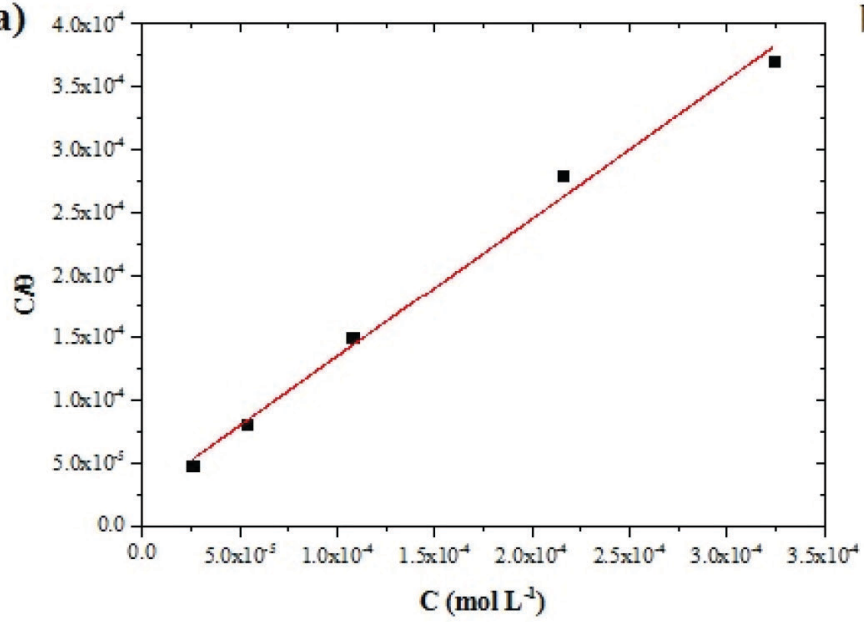

b)

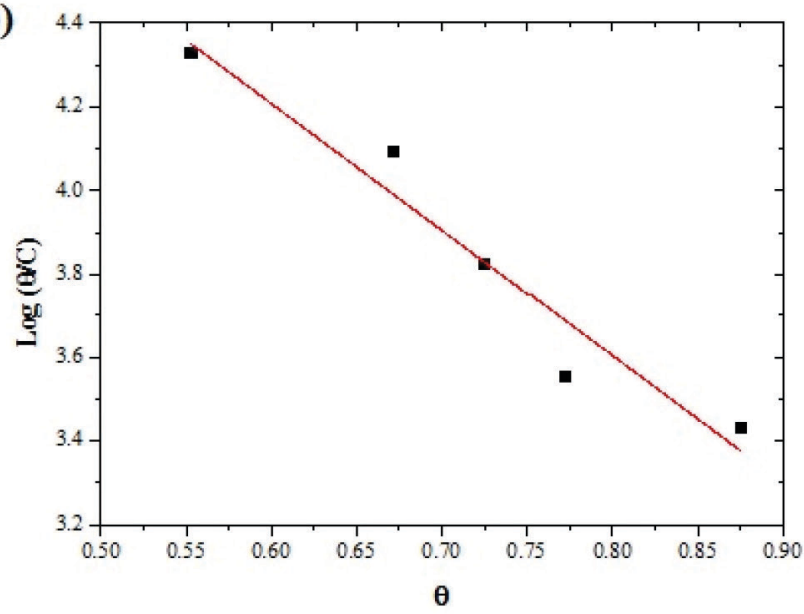

Figure 5. Langmuir (a) and Temkin (b) isotherm plots for AISI 1018 mild steel in saline medium (0.6 mol $L^{-1}$ NaCl), containing different concentrations of OAQX at $300 \mathrm{~K}$

Table 3. Parameters obtained from polarization curves for AISI 1018 mild steel, in saline medium $\left(0.6 \mathrm{~mol} \mathrm{~L}^{-1} \mathrm{NaCl}\right)$, containing OAQX at different concentrations

\begin{tabular}{|c|c|c|c|c|c|c|c|c|c|}
\hline $\begin{array}{c}\text { OAQX } \\
\left(\times 10^{-4} \mathrm{~mol} \mathrm{~L}^{-1}\right)\end{array}$ & $\begin{array}{c}\mathrm{i}_{\text {corr }} \\
\left(\mathrm{A} \mathrm{cm}^{-2}\right)\end{array}$ & $\begin{array}{c}-b_{\text {cathodic }} \\
\left(\mathrm{V} \mathrm{dec}^{-1}\right)\end{array}$ & $\begin{array}{c}b_{\text {anodic }} \\
\left(\mathrm{V} \mathrm{dec}^{-1}\right)\end{array}$ & $\begin{array}{c}\mathrm{Rp} \\
(\mathrm{Ohm})\end{array}$ & $\begin{array}{c}E_{\text {corr }} \text { observed } \\
\text { (V) }\end{array}$ & $\begin{array}{c}\mathrm{E}_{\text {corr }} \text { calculated } \\
(\mathrm{V})\end{array}$ & $\begin{array}{c}\text { Corrosion rate } \\
\left(\mathrm{mm} \text { year }^{-1}\right)\end{array}$ & $\begin{array}{l}\text { Degree of } \\
\text { recovery }(\theta)\end{array}$ & $\begin{array}{c}\text { Inhibition } \\
\text { efficiency }\left(\eta_{\mathrm{P}}\right)\end{array}$ \\
\hline $\mathrm{NaCl}^{*}$ & $1.29 \times 10^{-5}$ & 0.106 & 0.182 & $2.403 \times 10^{3}$ & -0.837 & -0.839 & $1.490 \times 10^{-1}$ & 0 & 0 \\
\hline 0.259 & $5.74 \times 10^{-6}$ & 0.123 & 0.197 & $6.750 \times 10^{3}$ & -0.800 & -0.812 & $6.663 \times 10^{-2}$ & 0.55 & 55.30 \\
\hline 0.541 & $4.22 \times 10^{-6}$ & 0.095 & 0.188 & $6.711 \times 10^{3}$ & -0.829 & -0.842 & $4.898 \times 10^{-2}$ & 0.67 & 67.14 \\
\hline 1.082 & $3.54 \times 10^{-6}$ & 0.161 & 0.167 & $1.207 \times 10^{4}$ & -0.736 & -0.734 & $4.102 \times 10^{-2}$ & 0.72 & 72.48 \\
\hline 2.159 & $2.92 \times 10^{-6}$ & 0.173 & 0.159 & $1.500 \times 10^{4}$ & -0.702 & -0.658 & $3.388 \times 10^{-2}$ & 0.77 & 77.28 \\
\hline 3.243 & $1.60 \times 10^{-6}$ & 0.073 & 0.082 & $4.368 \times 10^{3}$ & -0.634 & -0.648 & $1.855 \times 10^{-2}$ & 0.87 & 87.60 \\
\hline DMSO** & $1.56 \times 10^{-5}$ & 0.370 & 0.077 & $2.891 \times 10^{3}$ & -0.894 & -0.916 & $1.805 \times 10^{-1}$ & -0.21 & -2.09 \\
\hline
\end{tabular}

*Saline solution $\left(0.6 \mathrm{~mol} \mathrm{~L}^{-1} \mathrm{NaCl}\right)$ without the inhibitor $(\mathrm{OAQX})$. **Saline solution $\left(0.6 \mathrm{~mol} \mathrm{~L}^{-1} \mathrm{NaCl}\right)$ and DMSO $\left(0.627 \times 10^{-4} \mathrm{~mol} \mathrm{~L}^{-1}\right)$ without the inhibitor (OAQX).

Table 4. Adsorption parameters for OAQX corrosion inhibitor of AISI 1018 mild steel, in saline medium $\left(0.6 \mathrm{~mol} \mathrm{~L}^{-1} \mathrm{NaCl}\right)$

\begin{tabular}{ccccc}
\hline Isotherm & Equation & $\mathrm{R}^{2}$ & $\mathrm{~K}_{\mathrm{ads}}$ & $\begin{array}{c}\Delta \mathrm{G}_{\text {ads }}^{0} \\
\left(\mathrm{~kJ} \mathrm{~mol}^{-1}\right)\end{array}$ \\
\hline Langmuir & $\mathrm{y}=0.000024+1.1021 \mathrm{X}$ & 0.99 & $4.04 \times 10^{4}$ & -36.47 \\
Temkin & $\mathrm{y}=6.0187-3.0186 \mathrm{X}$ & 0.94 & $1.04 \times 10^{6}$ & -44.57 \\
\hline
\end{tabular}

$\mathrm{C}=\mathrm{C}$ and $\mathrm{C}=\mathrm{N}$, and bonds become broader in spectrum (Figure $6 \mathrm{~b}$ ) as a consequence of heterocyclic unit coordination to the iron surface. From the FTIR spectra analysis, it is also possible to suggest that oxygen of the heterocylic unit participates since the bands relative to C-O bonds of ether $\left(1203 \mathrm{~cm}^{-1}\right.$ and $\left.1056 \mathrm{~cm}^{-1}\right)$ are suppressed after interaction of OAQX with the metal. Lastly, one relevant finding from FTIR analysis arrives from the band at $1022 \mathrm{~cm}^{-1}$, relative to the $\mathrm{C}-\mathrm{O}$ bond of the primary alcohol moiety, which remains unchanged in spectra (Figure 6b) and (Figure 6c) (dashed line), and this feature strongly suggests that the hydroxyl group is not involved in the binding phenomena of OAQX adsorbed on the metallic surface. According to this analysis, the inhibition mechanism onto mild steel by OAQX involves its $\mathrm{N}=\mathrm{C}-\mathrm{O}$ triad interactions on a metallic surface, in which the polarization effect originated from the conjugation of a lone pair of oxygen atoms with the heteroaromatic system may be crucial to the adsorption. In fact, this proposed mechanism is also consistent with an unlikely chelation proceeding through $\mathrm{N}=\mathrm{C}-\mathrm{N}$ triad due to a steric factor originated from the hydroxyethyl branch. One relevant goal associated to this mechanistic proposal consists in the fact that the herein reported corrosion inhibitor is easily prepared and has a hydroxyl group subjected to a future chemical transformation currently being developed in our laboratory, in attempt to obtain polymeric species based on the oxazine-quinoxaline moiety, and

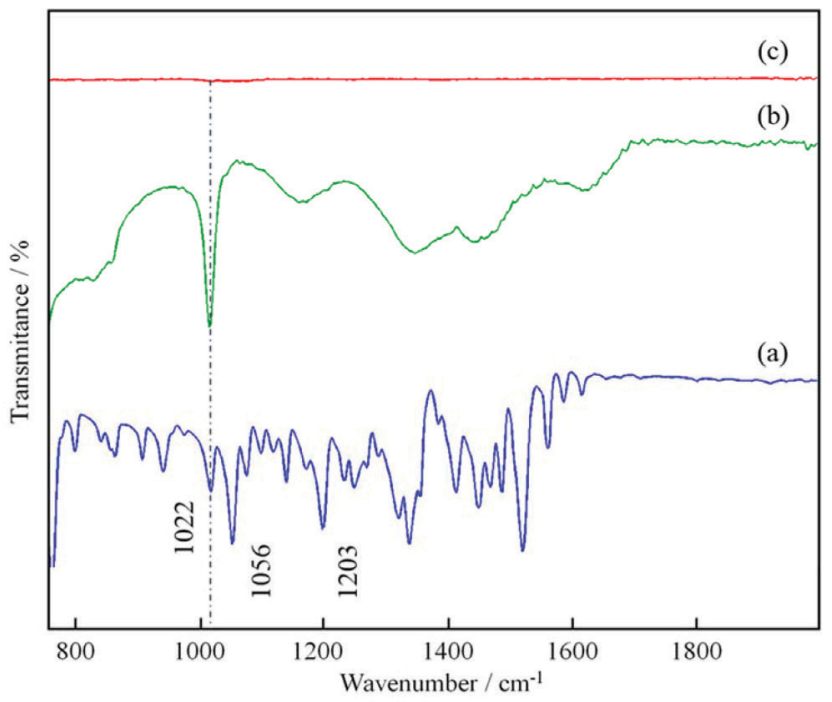

Figure 6. FTIR spectra $\left(700 \mathrm{~cm}^{-1}-2000 \mathrm{~cm}^{-1}\right)$ of the crystalline OAQX (a); and of mild steel exposed for $72 \mathrm{~h}$ in saline medium $\left(0.6 \mathrm{~mol} \mathrm{~L}^{-1} \mathrm{NaCl}\right)$, in the presence of $3.243 \times 10^{-4} \mathrm{~mol} \mathrm{~L}^{-1}$ of OAQX (b) and in the absence of OAQX (c) 
aiming at higher inhibition of the corrosion process induced by a simulated marine environment.

\section{Computational calculations}

Due to the relevance of the computational research in evaluating corrosion inhibitor capacity, a quantum theoretical study was performed in order to support the experimental results obtained for the action of OAQX in the prevention of corrosion of mild steel. The method employed was the hybrid B $3 \mathrm{LYP},{ }^{30}$ which has been found to present good results for understanding the inhibitory ability of several compounds, ${ }^{33}$ combined with $6-311++\mathrm{G}(\mathrm{d}, \mathrm{p})$ basis set. DFT calculations were performed in gas phase using a Gaussian Program. ${ }^{31}$

The first step of the theoretical study was based on optimization of structural and electronic parameters, in addition to calculations of frontiers molecular orbital density (HOMO and LUMO) distributions of ligand OAQX (Figure 7 and Table 5). From the optimized structure, it is possible to verify that the quinoxaline derivative herein reported has an extended planar portion comprising the quinoxaline moiety and both oxygen and nitrogen atoms directly bonded to this heterocyclic unit (Figure 7a). Another relevant factor to be evaluated is the OAQX charge distribution which was found to be rich in the region comprising both nitrogen and oxygen atoms linked to the same carbon atom $(\mathrm{N} 13=\mathrm{C} 14-\mathrm{O} 1$ system $)$, and being more appropriate to undergo chelation with the metal surface. In fact, these atoms are presented in a planar portion of the OAQX, leading to a larger ligand-metal surface area for chemical adsorption (Figures $7 \mathrm{a}$ and $7 \mathrm{~b}$ ), justifying

(a)

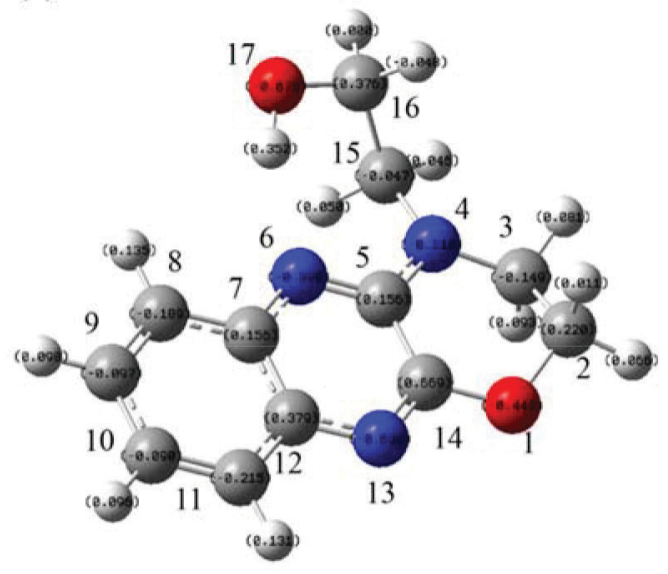

(c)

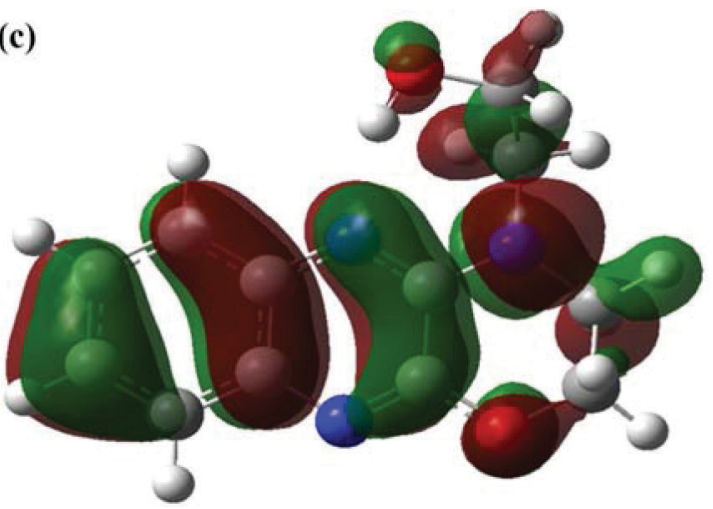

the experimental results of OAQX as an efficient corrosion inhibitor.

The adsorption mechanism based in both FTIR experiment and structural parameters extracted from quantum calculations is also supported by analyzing the frontier molecule orbital on the ligand structure, which can be a very useful tool for understanding the molecular reactivity of organic inhibitors ${ }^{36,37}$ such as OAQX. Both HOMO and LUMO are well distributed over the heteroaromatic system and also at the other heteroatoms, as presented in Figures $7 \mathrm{c}$ and $7 \mathrm{~d}$, respectively. The calculated energies for $\mathrm{HOMO}\left(\mathrm{E}_{\text {номо }}\right)$ and LUMO ( $\mathrm{E}_{\text {LUMO }}$ ) were $-6.110 \mathrm{eV}$ and $-1.984 \mathrm{eV}$ (Table 5), which are in very good agreement with other quinoxaline derivatives reported in literature as effective corrosion inhibitors for mild steel..$^{2,4,20,33}$ The electron donating ability of a given molecule is often associated to its $\mathrm{E}_{\text {номо }}$, being the more favorable process as the value becomes higher. On the other hand, as $\mathrm{E}_{\mathrm{LUMO}}$ becomes smaller, the possibility of the organic compound to accept electronic density increases. In such structural systems like this, which involves a nitrogen aromatic heterocyclic derivative adsorbing to a metal surface, both electron donation from HOMO of the ligand to empty d-orbital of the metal as well and retro-donation (electrons from d-orbital of the metal to the LUMO of the organic compound) are quite possible. In fact, the $\Delta \mathrm{E}_{\text {gap }}(4.216 \mathrm{eV})$ is consistent with the possibility of $\mathrm{Fe}-\mathrm{L}$ interacting, leading to stable complexes. ${ }^{33}$ As already mentioned, chelation for the N4=C5-N6 triad is unlikely to proceed due to steric factors, but also due to the lower density distribution.

The OAQX computational study also allowed for obtaining several relevant parameters, such as dipole moment $(\mu)$, electronic affinity (A), ionization potential (I), absolute electronegativity $(\chi)$,
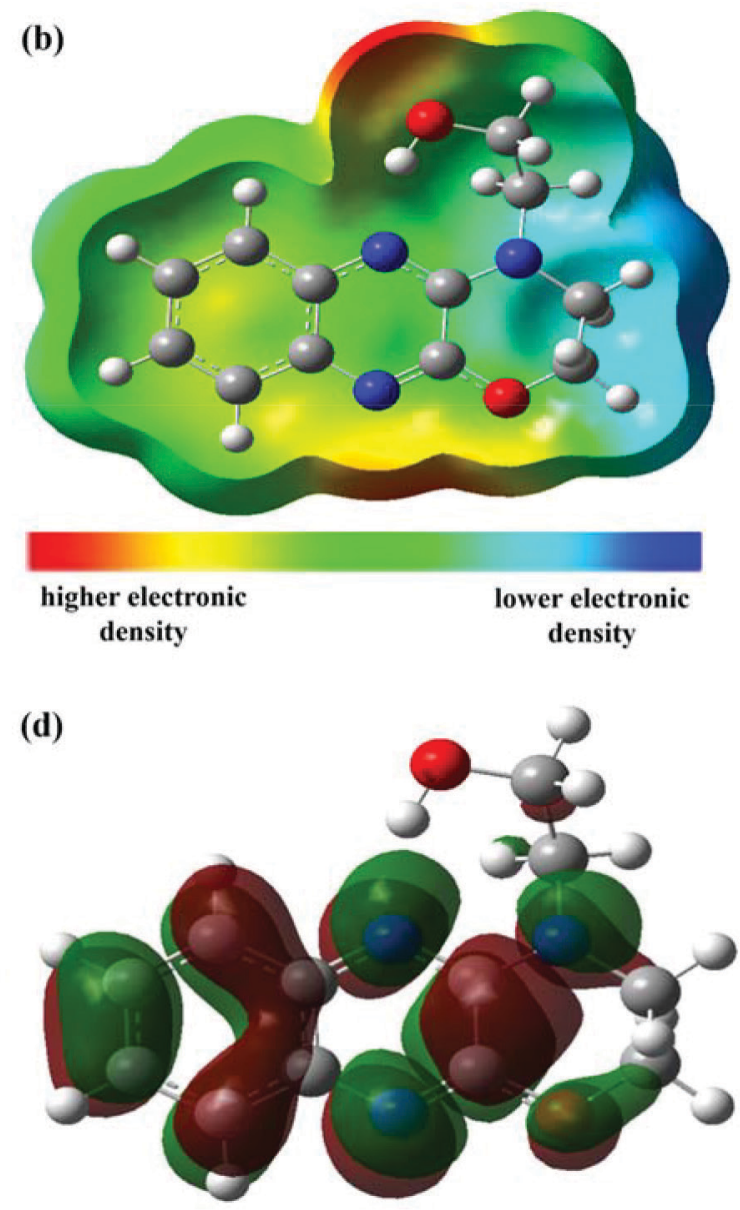

Figure 7. Quantum chemical results of OAQX calculated by the DFT/B3LYP method with 6-311G++(d,p) basis set: (a) optimized molecular structure with numbered atoms; (b) total electron density surface mapped with electrostatic potential; (c) HOMO distribution; (d) LUMO distribution 
global hardness $(\gamma)$ and fraction of electron transferred $(\Delta \mathrm{N})$, as presented in Table 5. Although the dipole moment $(\mu)$ is reported as being relevant to evaluate the adsorption ability of organic inhibitors, the correlation of quantum parameter and the corrosion effectiveness is contradictory, since while high and low $\mu$ values could suggest, respectively, strong dipole-dipole interactions and accumulation to/on the metallic surface. ${ }^{3}$ In this work, the dipole moment found for OAQX was 3.876 Debye, which is in the same magnitude of other corrosion inhibitors. The calculated fraction of electrons transferred $(\Delta \mathrm{N})$ from the OAQX inhibitor to the metal surface, was found to be 0.711 , and this value is consistent with a situation of good electrondonating by the organic inhibitor to the metal surface. ${ }^{36,38}$

Table 5. Quantum chemical parameters for OAQX using B3LYP/6$-311 \mathrm{G}++(\mathrm{d}, \mathrm{p})$ level in gas phase

\begin{tabular}{cc}
\hline Calculated parameter for OAQX & Value \\
\hline $\mathrm{E}_{\text {Hомо }}(\mathrm{eV})$ & -6.110 \\
$\mathrm{E}_{\text {LUмо }}(\mathrm{eV})$ & -1.894 \\
$\Delta \mathrm{E}_{\text {gap }}(\mathrm{eV})$ & 4.216 \\
$\chi(\mathrm{eV})$ & 4.002 \\
$\gamma(\mathrm{eV})$ & 2.108 \\
$\Delta \mathrm{N}$ & 0.711 \\
$\mu($ Debye $)$ & 3.876 \\
Molecular weight $(\mathrm{amu})$ & 231.250 \\
Charge on O1 & -0.449 \\
Charge on N4 & -0.638 \\
Charge on N6 & -0.118 \\
Charge on N13 & -0.399 \\
\hline
\end{tabular}

\section{CONCLUSIONS}

This work reports the OAQX corrosion inhibition ability against the corrosion of AISI 1018 mild steel induced by aqueous $0.6 \mathrm{~mol} \mathrm{~L}^{-1}$ $\mathrm{NaCl}$ solution. The oxazinoquinoxaline derivative OAQX dissolved in DMSO, and then diluted in this saline solution afforded the OAQX tested samples $\left(3.243 \times 10^{-4} \mathrm{~mol} \mathrm{~L}^{-1}, 2.159 \times 10^{-4} \mathrm{~mol} \mathrm{~L}^{-1}\right.$, $1.082 \times 10^{-4} \mathrm{~mol} \mathrm{~L}^{-1}, 0.541 \times 10^{-4} \mathrm{~mol} \mathrm{~L}^{-1}$, and $\left.0.259 \times 10^{-4} \mathrm{~mol} \mathrm{~L}^{-1}\right)$. From that, the inhibitory efficiency of OAQX varying from $62.75 \%$ to $75.93 \%$ by using linear polarization resistance ( $\mathrm{Rp}$ ) studies. The OAQX electrochemical behavior at saline $\left(0.6 \mathrm{~mol} \mathrm{~L}^{-1} \mathrm{NaCl}\right)$ solution by Tafel extrapolation method showed OAQX efficiency ranging from $55.30 \%$ to $87.60 \%$. The higher effectiveness of OAQX corrosion inhibition on both methods Rp as well as Tafel approach was favored at higher OAQX tested samples concentrations (2.159 x $10^{-4} \mathrm{~mol} \mathrm{~L}^{-1}$ and $3.243 \times 10^{-4} \mathrm{~mol} \mathrm{~L}^{-1}$, respectively). The best description of the OAQX optimized adsorption parameter on the mild steel surface $\left(\mathrm{R}^{2}=0.99\right)$ is evidenced to the Langmuir isotherm with a negative value of $\left(-36.47 \mathrm{~kJ} \mathrm{~mol}^{-1}\right)$. OAQX showed exothermic and spontaneous process, considered as chemisorption phenomena, because it was found to be upon to $|20| \mathrm{kJ} \mathrm{mol}^{-1}$. This find was reinforced by the adsorption mechanism proposed by FTIR and quantum theoretical studies. Specifically, FTIR and the quantum chemical calculations results allowed for suggesting a mechanism in which OAQX adsorbs to the metal surface, mainly by the $\mathrm{N}=\mathrm{C}-\mathrm{O}$ site. Studies of corrosion inhibition from chloride rich environments are currently highlighted due to the large number of petroleum natural reservoirs found in underwater marine soil, justifying the $0.6 \mathrm{~mol} \mathrm{~L}^{-1} \mathrm{NaCl}$ saline media.

\section{SUPPLEMENTARY MATERIAL}

Supplementary information on the metallographic analysis and electrochemical measurements can be found at http://quimicanova. sbq.org.br in PDF format, with free access.

\section{ACKNOWLEDGMENTS}

The authors would like to give thanks for the financial support from the Brazilian Conselho Nacional de Desenvolvimento Científico e Tecnológico (CNPq), Coordenação de Aperfeiçoamento de Pessoal de Nível Superior (CAPES), and Fundação de Amparo à Pesquisa do Rio Grande do Norte (FAPERN), as well as the Federal University of Rio Grande do Norte (UFRN). The authors also acknowledge Dr. C. A. Martinez-Huitle for making available the instrument for LPR analysis (located at the LEAA, Laboratório de Eletroquímica Ambiental e Aplicada) and also we are grateful to Dr. Almir Mirapalheta for valuable guidance.

\section{REFERENCES}

1. Goulart, C. M.; Esteves-Souza, A.; Martinez-Huitle, C. A.; Rodrigues, C. J. F.; Maciel, M. A. M.; Echevarria, A.; Corros. Sci. 2013, 67, 281.

2. Zarrouk, A.; Hammouti, B.; Dafali, A.; Bouachrine, M.; Zarrok, H.; Boukhris, S.; Al-Deyab, S. S.; J. Saudi Chem. Soc. 2014, 18, 450.

3. Felipe, M. B. M. C.; Silva, D. R.; Martinez-Huitle, C. A.; Medeiros, S. R. B.; Maciel, M. A. M.; Mat. Corros. 2013, 64, 530.

4. Adnani, Z. E.; Mcharfi, M.; Sfaira, M.; Benzakour, M.; Benjelloun, A. T.; Touhami, M. E.; Corros. Sci. 2013, 68, 223.

5. Gutiérrez, E.; Rodríguez, J. A.; Cruz-Borbolla, J.; Alvarado-Rodríguez, J. G.; Thangarasu, P.; Corros. Sci. 2016, 108, 23.

6. Behzadnasab, M.; Mirabedini, S. M.; Kabiri, K.; Jamali, S.; Corros. Sci. 2011, 53, 89.

7. Finšgar, M.; Jackson, J.; Corros. Sci. 2014, 86, 17.

8. Qian, B.; Hou, B.; Zheng, M.; Corros. Sci. 2013, 72, 1.

9. Malik, M. A.; Hashim, M. A.; Nabi, F.; AL-Thabaiti, S. S.; Khan, Z.; Int. J. Electrochem. Sci. 2011, 6, 1927.

10. Jawich, M. W. S; Oweimreen, G. A.; Ali, S. A.; Corros. Sci. 2012, 65, 104.

11. Prabha, S. S.; Rathish, R. J.; Dorothy, R.; Brindha, G.; Pandiarajan, M.; Al-Hashem, A.; Rajendran, S.; Eur. Chem. Bull. 2014, 3, 300.

12. Finšgar, M.; Petovar, B.; Xhanari, K.; Maver, U.; Corros. Sci. 2016, 111, 370.

13. Flores, E. A.; Olivares, O.; Likhanova, N. V.; Domínguez-Aguilar, M. A.; Nava, N.; Guzman-Lucero, D.; Corrales, M.; Corros. Sci. 2011, 53, 3899.

14. Ali, S. A.; Al-Muallem, H. A.; Rahman, S. U.; Saeed, M. T.; Corros. Sci. 2008, 50, 3070.

15. Teixeira, D. A.; Valente JR., M. A. G.; Benedetti, A. V.; Feliciano, G. T.; Silva, S. C.; Fugivara, C. S. Experimental and Theoretical Studies of Volatile Corrosion Inhibitors Adsorption on Zinc Electrode. J. Braz. Chem. Soc. 2015, 26, 434.

16. Bentiss, F.; Lagrenee, M.; Traisnel, M.; Homez, J. C.; Corros. Sci. 1999, 41,789 .

17. Li, W.; He, Q.; Zhang, S.; Pei, C.; Hou, B.; J. Appl. Electrochem. 2008, 38,289

18. Ferreira, E. S.; Giacomelli, C.; Giacomelli, F. C.; Spinelli, A.; Mat. Chem. Phys. 2004, 83, 129.

19. Popova, A.; Sokolova, E.; Raicheva, S.; Christov, M.; Corros. Sci. 2003, 45,33 .

20. Obot, I. B.; Obi-Egbedi, N. O.; Odozi, N. W.; Corros. Sci. 2010, 52, 923.

21. Chitra, S.; Parameswari, K.; Vidhya, M.; Kalishwari, M.; Selvaraj, A.; Int. J. Electrochem. Sci. 2011, 6, 4593. 
22. El-Hajjaji, F.; Belzkmima, R. A.; Zerga, B.; Sfaira, M.; Taleb, M.; Touhami, M. E.; Hammouti, B.; Al-Deyab, S. S.; Ebenso, E.; Int. J. Eletrochem. Sci. 2014, 9, 4721.

23. Obot, I. B.; Obi-Egbedi, N. O.; Mat. Chem. Phys. 2010, 122, 325.

24. Abboud, Y.; Abourriche, A.; Saffaj, T.; Berrada, M.; Charrouf, M.; Bennamara, A.; Himidi, N. A.; Hannache, H.; Mat. Chem. Phys. 2007, $105,1$.

25. Obot, I. B.; Obi-Egbedi, N. O.; Corros. Sci. 2010, 52, 282.

26. Mora, E. C. M.; Souza, A. D. N.; Rossi, C. G. F. T.; Silva, D. R.; Maciel, M. A. M.; Echevarria, A.; Bellieny, M. S. S.; Quim. Nova 2013, 36, 59.

27. Ajani, O. O.; Eur. J. Med. Chem. 2014, 85, 688.

28. Achelle, S.; Baudequin, C.; Plé, N.; Dyes Pig. 2013, 98, 575.

29. Obafemi, C. A.; Pfleiderer, W.; Taiwo, F.; Molbank 2006, M508.

30. Tirado-Rives, J.; Jorgensen, W. L.; J. Chem. Theory Comput. 2008, 4, 297.

31. Frisch, M. J.; Trucks, G. W.; Schlegel, H. B.; Scuseria, G. E.; Robb, M. A.; Cheeseman, J. R.; Scalmani, G.; Barone, V.; Mennucci, B.; Petersson, G. A.; Nakatsuji, H.; Caricato, M.; Li, X.; Hratchian, H. P.; Izmaylov, A. F.; Bloino, J.; Zheng, G.; Sonnenberg, J. L.; Hada, M.; Ehara, M.; Toyota, K.; Fukuda, R.; Hasegawa, J.; Ishida, M.; Nakajima, T.; Honda, Y.; Kitao, O.; Nakai, H.; Vreven, T.; Montgomery Jr., J. A.; Peralta, J. E.; Ogliaro, F.; Bearpark, M.; Heyd, J. J.; Brothers, E.; Kudin,
K. N.; Staroverov, V. N.; Kobayashi, R.; Normand, J.; Raghavachari, K.; Rendell, A.; Burant, J. C.; Iyengar, S. S.; Tomasi, J.; Cossi, M.; Rega, N.; Millam, J. M.; Klene, M.; Knox, J. E.; Cross, J. B.; Bakken, V.; Adamo, C.; Jaramillo, J.; Gomperts, R.; Stratmann, R. E.; Yazyev, O.; Austin, A. J.; Cammi, R.; Pomelli, C.; Ochterski, J. W.; Martin, R. L.; Morokuma, K.; Zakrzewski, V. G.; Voth, G. A.; Salvador, P.; Dannenberg, J. J.; Dapprich, S.; Daniels, A. D.; Farkas, O.; Foresman, J. B.; Ortiz, J. V.; Cioslowski, J.; Fox D. J.; Gaussian 09, Revision D. 01, Gaussian, Inc., Wallingford CT, 2009.

32. Breneman, C. M.; Wiberg, K. B.; J. Comput. Chem. 1990, 11, 361.

33. Daoud, D.; Douadi, T.; Hamani, H.; Chafaa, S.; Al-Noaimi, M.; Corros. Sci. 2015, 94, 21.

34. Valek, L.; Martinez, S.; Mikulić, D.; Brnardić, I.; Corros. Sci. 2008, 50, 2705.

35. Puthalath, R.; Surendranathan, A. O.; Murthy, C. S. N.; Ind. Eng. Chem. Res. 2014, 53, 23.

36. Rochdi, A.; Kassou, O.; Dkhireche, N.; Touir, R.; Bakri, M. E.; Touhami, M. E.; Sfaira, M.; Mernari, B.; Hammouti, B.; Corros. Sci. 2014, 80, 442.

37. Sastri, V. S.; Perumareddi, J. R.; Corros. 1997, 53, 617.

38. Lukovits, I.; Kálmán, E.; Zucchi, F.; Corros. Sci. 2001, 57, 3. 